\title{
Amino Acid Sequences of Proteins from Leptospira Serovar pomona
}

\author{
Selmo F Alves ${ }^{+}{ }^{\text {, Rance B LeFebvre*, William Probert* }}$
}

\author{
Embrapa Caprinos, Fazenda Três Lagoas, Caixa Postal D-10, 62011-970 Sobral, CE, Brasil *University of \\ California, Davis/Department of Veterinary Microbiology, Immunology and Pathology, 95616-Davis, CA, USA
}

This report describes a partial amino acid sequences from three putative outer envelope proteins from Leptospira serovar pomona. In order to obtain internal fragments for protein sequencing, enzymatic and chemical digestion was performed. The enzyme clostripain was used to digest the proteins 32 and $45 \mathrm{kDa}$. In situ digestion of $40 \mathrm{kDa}$ molecular weight protein was accomplished using cyanogen bromide. The $32 \mathrm{kDa}$ protein generated two fragments, one of $21 \mathrm{kDa}$ and another of $10 \mathrm{kDa}$ that yielded five residues. A fragment of $24 \mathrm{kDa}$ that yielded nineteen residues of amino acids was obtained from $45 \mathrm{kDa}$ protein. A fragment with a molecular weight of $20 \mathrm{kDa}$, yielding a twenty amino acids sequence from the $40 \mathrm{kDa}$ protein.

Key words: Leptospira - proteins - amino acid - sequence

Leptospirosis is an economically important zoonosis occurring worldwide (Ellis 1986). Host immune defense mechanisms in leptospirosis are mainly humoral (Adler et al. 1980) with production of specific antibodies primarily to the outer envelope antigens. Whole cell (Bey 1982) and outer envelope antigens (Auran et al. 1972, Zuerner et al. 1991) have been extracted from leptospiras by different methods and proven to be immunogenic. Investigators isolated and characterized the outer envelope proteins in the range of 22 to 66 $\mathrm{kDa}$ from Leptospira interrogans using different detergent and extraction methods (Nunes et al. 1985, Brown et al. 1991, Haake et al. 1991, Zuerner et al. 1991). Haake et al. (1991) and Zuerner et al. (1991) used Triton X-114 extraction to isolate and characterize outer envelope antigens of serovar grippotyphosa and pomona, respectively. They concluded that these detergent phase proteins were related to integral membrane proteins. Alves (1993) used this method to isolate detergent-phase proteins from six common serovars. Three major $(32,40,45 \mathrm{kDa})$ and one minor $(22 \mathrm{kDa})$ protein were common to several serovars. These proteins

Financial support by CNPq and Embrapa (Brazil).

${ }^{+}$Corresponding autor. Fax: +55-88-612.1132. E-mail: selmo@cnpc.embrapa.br

Received 8 April 1999

Accepted 28 July 1999 were analyzed by sodium dodecyl sulfate-polyacrylamide gel electrophoresis (SDS-PAGE) and western blotting and demonstrated to be immunologically conserved in all serovars tested. The objective of this investigation was to partially characterize the 32, 40 and $45 \mathrm{kDa}$ antigens of Leptospira serovar pomona through internal amino acid sequencing. One serovar pomona was propagated in Bacto Leptospira Medium Base EMJH supplemented with 10\% Bacto Letospira Enrichment EMJH and incubated at $30^{\circ} \mathrm{C}$ for 7 to 10 days. Extraction and phase partitioning of outer envelope leptospiral proteins were performed with Triton X114 as previous described (Bordier 1981). The detergent-phase proteins were resolved on $12 \%$ acrylamide gels (Laemmli 1970) and transferred to Immobilon polyvinylidene difluoride (PVDF) membranes using a semidry blotting system. The membranes were washed ( 3 times in Milli-Q $\mathrm{ddH}_{2} \mathrm{O}$ ), stained with $0.1 \%$ Ponceau $\mathrm{S}$ and the desired proteins excised for sequencing. To obtain internal sequence information the $32 \mathrm{kDa}$ and 45 $\mathrm{kDa}$ were cleaved with clostripain (Arg-C). Nonspecific protein binding was prevented incubating the membranes (room temperature for 3-5 min) with $1 \%$ polyvinylpyrollidone in $\mathrm{MeOH}(500 \mu \mathrm{l})$. Briefly, the membranes were washed in sterile Milli-Q $\mathrm{ddH}_{2} \mathrm{O}$ and imersed in $50 \mu \mathrm{l}$ of $20 \mathrm{mM}$ Tris pH 7.6 containing $1 \mathrm{mM} \mathrm{CaCl}_{2}, 5 \mathrm{mM}$ DTT. After heating $\left(10 \mathrm{~min}\right.$ at $\left.80^{\circ} \mathrm{C}\right)$ and cooling, the digestion $\left(12 \mathrm{~h}\right.$ at $\left.37^{\circ} \mathrm{C}\right)$ took place by adding $1 \mu \mathrm{g}$ of the enzyme. The peptides were eluted with $70 \%$ isopropanol/1\% TFA solution $(100 \mu \mathrm{l}, 30 \mathrm{~min}$ at 
room temperature) and dried using a concentrator evaporator.

In situ digestion (room temperature, $24 \mathrm{~h}$ in the dark) of the $40 \mathrm{kDa}$ protein was accomplished adding $1.4 \mathrm{mg}$ of CNBr dissolved in $70 \%$ formic acid. The peptides were eluted (two times) with $50 \mathrm{mM}$ Tris, pH 9.2, containing 2\% SDS and $1 \%$ Triton $\mathrm{X}-100$.

For N-terminal amino acid sequence, both pooled eluates were subjected to SDS-PAGE (15\% acrylamide, Schagger \& Jagon 1987) and transferred to PVDF or Pro-blot membranes as described before (Matsudaira 1987). The bands were detected with $0.1 \%$ (w/v) Coomassie Brilliant Blue $\mathrm{R}-250$ in 50\% HPLC methanol grade and the peptides sequenced on a pulser-liquid automated sequencer (model ABI 477; Applied Biosystems, Foster City, CA).

The enzymatic cleavage of the $32 \mathrm{kDa}$ protein with clostripain (Arg-C) generated a10 kDa fragment with the following sequence I K I P N (P) and one addition with $21 \mathrm{kDa}$ not sequenced. A 24 $\mathrm{kDa}$ fragment could be obtained from the $45 \mathrm{kDa}$ protein using the same enzyme. In this case, the polypeptide presented the sequence A A A Q N T E G G T G L Q Y N (S) G A N D. The chemical cleavage of the $40 \mathrm{kDa}$ protein with $\mathrm{CNBr}$ generated a major fragment with $20 \mathrm{kDa}$ (L I P L D A T L I K V E T G E (S) K K A I V).

Data bank comparison (NBRF Protein and Swiss Protein) revealed a highly similarities of the 32, 40 and $45 \mathrm{kDa}$ of L. pomona (95.2 and 90.5\%) with L. interans (accession number U31426LppL1) and L. kruschnersi (accession number L46794), respectively. The impossibilty of the 32 $\mathrm{kDa}$ to be sequenced (data not shown) suggests that this protein may contains the $\mathrm{N}$-terminus acylated, a characteristic of lipoproteins, as that of Borrelia burgdorferi (Brandt et al. 1990). Thus, assuming that the 32,40 and $45 \mathrm{kDa}$ proteins are also acylated proteins, the strategy used in this study to identify the L. pomona antigens sequence seems to be fundamented to characterize the proteins. The obtention of amino acid sequence from these proteins would be also useful to design synthetic oligonucleotides that may allow the identification and cloning of the respective genes.

\section{REFERENCES}

Adler B, Faine S, Muller HK, Green DE 1980. Maturation of the humoral immuune response determines the susceptibility of guinea pigs to leptospirosis. Pathology 12: 529-538.

Alves FSF 1993. Immunochemical and Protection Studies of Leptospira, Thesis, Univ. da California, Davis, $86 \mathrm{pp}$.

Auran NE, Johnson RC, Ritzi DM 1972. Isolation of the outer sheath of Leptospira and its immunogenic properties in hamsters. Infect Immun 5: 968-975.

Bey RF, Johnson RC 1982. Immunogenicity and humoral and cell-mediated immune responses to leptospiral whole cell, outer envelope, and protoplasmic cylinder vaccines in hamstrer and dogs. Am J Vet Res 43: $835-840$

Bordie C 1981. Phase separation of integral membrane proteins in Triton X-114. J Biol Chem 256: 1604 1607.

Brandt ME, Riley BS, Radolf KD, Norgard MV 1990. Immunogenic integral membrane proteins of Borrelia burgdorferi are lipoproteins. Infect Immun 58: 983-991.

Brown JA, LeFebvre RB, Pan MJ 1991. Protein and antigen profiles of prevalent serovars of Leptospira interrogans. Infect Immun 59: 1772-1777.

Ellis WA 1986. Leptospirosis. J. Small Anim Pract 27: 683-692.

Haake DA, Walker EM, Blanco DR, Bolin CA, Miller JN, Lovett MA 1991. Changes in the surface of Leptospira interrogans serovar grippotyphosa during in vitro cultivation. Infect Immun 59: 1131-1140.

Laemmli UK 1970. Cleavage of structural proteins during the assembly of the head of bacteriophage T4. Nature (London) 227: 680-685.

Matsudaira P 1987. Sequence from picomole quantities of proteins electroblotted onto polyvinylidene difluoride membranes. J Biol Chem 262: 10035 10038.

Nunes-Edwards PL, Thiermann AB, Bassford Jr PJ, Stamm LV 1985. Identification and characterization of the protein antigens of Leptospira interrogans serovar hardjo. Infec Immun 48: 492-497.

Schagger H, Jagon GV 1987. Tricine-sodium dodecyl sulphate-polyacrylamide gel electrophoresis for the separation of proteins in the range from 1 to 100 kDa. Anal Biochem 166: 368-379.

Zuerner RL, Knudtson W, Bolin CR, Trueba G 1991. Characterization of outer membrane and secreted proteins of Leptospira interrogans serovar pomona. Microb Pathogenesis 10: 311-322. 